Jankowska, A., (2019). Training future describers - a practice report from an audio description classroom. Linguistica Antverpiensia, New Series: Themes in Translation Studies, 18, 197-215.

\title{
Training future describers: A practice report from an audio description classroom
}

\author{
Anna Jankowska \\ Jagiellonian University in Krakow, Poland \\ anna.m.jankowska@uj.edu.pl \\ http://orcid.org/0000-0001-6863-5940
}

\begin{abstract}
Over the past few years, we have been observing an exponential growth in audio description (AD). This has resulted in a growing need for trained $A D$ professionals and, consequently, for $A D$ training. While the ADLAB PRO project helped define the professional profile of the audio describer and produced a range of training materials, there is still considerable room for other $A D$ training approaches to be shared with a view to inspiring $A D$ trainers when creating their courses. Thus, this practice report presents selected exercises that I have been developing since 2009, when I first started teaching AD both at university and outside academia (e.g., during dedicated courses for broadcasters, NGOs and cultural institutions), presenting their learning outcomes and framing them within the ADLAB PRO framework of competencies for professional audio describers. All the activities offered in this article are based on my professional experience as an academic teacher and researcher and also as a professional describer and accessibility manager who overlsees the entire AD production process: from negotiating with clients through production (scripting, proofs, recording, quality control) to product delivery and on-site assistance.
\end{abstract}

Keywords: audio descritpion, audiovisual translation, accessibility, teaching

\section{Introduction}

In recent years we have been observing an exponential growth in audio description (AD), both in research and, perhaps even more importantly, in practice. Legislation introduced at the global, ${ }^{1}$ European ${ }^{2}$ and national ${ }^{3}$ levels prompted the industry to introduce access services. This resulted in a growing need for trained $A D$ professionals and, consequently, for $A D$ training. New legislation that recently came into play - the European Accessibility $\mathrm{Act}^{4}-$ will increase this demand even further.

$A D$ training is now offered at various levels ${ }^{5}$ (e.g., university courses at graduate or postgraduate level, professional training courses), yet a consistent definition of a describer's competences is still lacking. It would, however, be untruthful to say that the issue has been completely overlooked, because both researchers and practitioners have tried to define the competences needed and have published on this topic (Díaz-Cintas, 2007; Evangelina, Peralta, 
Jankowska, A., (2019). Training future describers - a practice report from an audio description classroom. Linguistica Antverpiensia, New Series: Themes in Translation Studies, 18, 197-215.

Guajardo, Sotomayor, \& Lemus, n.d.; Hyks, 2005; Matamala, 2006; Matamala \& Orero, 2007; Navarrete Moreno, 1997; Orero, 2005; Sadowska, 2014; Snyder, 2014). Some information is also provided by organizations that offer professional training (e.g., Access2Arts, n.d.; Audio Description Association, n.d.). However, it should be noted that none of the attempts mentioned above are supported by research evidence nor do they constitute a comprehensive framework comparable to models such as, for example, the European Master's in Translation (European Commission, 2017) or PACTE (Hurtado Albir, 2017), known in Translation Studies. Hopefully, this will change as ADLAB PRO ${ }^{6}$ - the first large-scale project that aimed at defining the professional profile of an audio describer and at designing dedicated training materials was in place between 2016 and 2019.

Teaching materials are another burning issue in AD training. It would not be an exaggeration to say that, until very recently, apart from a few exceptions (Fryer, 2016; Jankowska, 2017; Matamala \& Orero, 2007; Sadowska, 2014; Snyder, 2014), hardly any training materials were generally available. Although, as already mentioned, in 2019, a set of freely available online materials was created by the ADLAB PRO project (see more at www.adlabpro.eu/course materials/), it is still a drop in the ocean, especially when compared to the resources available for translator training, for example. Because of that, AD trainers base the curricula and training materials they produce on guidelines, research results or simply on what they believe is relevant.

This article attempts to contribute to that by presenting selected activities that I have been developing since 2009, when I first started teaching AD both at university and outside academia. I do not pretend to have created an exhaustive competence model or even to tackle all the major competences and skills needed by describers. But I do want to share part of my personal experience for others to assess, analyse, use and, hopefully, to gain something from. But I hope that others will also criticize, discuss and dispute, so that the gain is mutual. This article should be regarded as a practice report, hence the personal rather than the academic tone.

The article starts with a brief explanation of my pedagogical approach, which is placed within the integrative functional approach (Biel, 2013) combined with active and exploratory learning. Then sample exercises are presented and discussed. An attempt is made to place the discussed exercises within the ADLAB PRO competence framework for the professional audio describer ( $A D L A B P R O, 2018$ ). All of them focus mainly on teaching $A D$ scripting and are organized in the following modules, which are also sub-sections of this article: First steps in AD scripting (3.1), AD translation (3.2), Learning and questioning the guidelines (3.3), From rules to strategies (3.4) and Collaborative AD scripting (3.4).

\section{Pedagogical approach}

The approach I take in class is based on what Biel (2013) calls the integrative functional approach, which draws upon the professional realism of training, social constructivism and functionalism. It also combines a teacher-centred approach with a student-centred approach to gradually move from teacher-assisted to autonomous learning. While I value and use the more traditional approach of offering knowledge through lectures and readings, I try to build my teaching on the principles of active and discovery learning that involves the trainees in the 
Jankowska, A., (2019). Training future describers - a practice report from an audio description classroom. Linguistica Antverpiensia, New Series: Themes in Translation Studies, 18, 197-215.

learning process through a variety of exercises (e.g., discussion, problem-solving, pro-con grids, brainstorming, think-pair-share) that promote inductive rather than deductive learning (Bonwell \& Eison, 1991; Felder, Celanese, \& Brent, 2009).

However, one thing should be pointed out from the outset: I believe that the best way to achieve the goal of training successful describers is through intertwining theory with practice. Anyone who has ever taught audiovisual translation (AVT) or AD must have noticed that trainees are usually highly practice-oriented. They want to learn how to write, how to cue, how to use the software, etc. At the mere sound of the word "theory", they seem - at the very best - to become discouraged, since they think that theory is not useful in professional practice. The relationship between theory and practice is not an easy one. However, given my double background as practisearcher, I am strongly convinced that in the case of $A D$, it is a reciprocal relationship in which theory informs practice and practice informs theory.

There are three areas in which, I think, AD theory can help future describers. First, instead of providing ready-made solutions, it gives tools that will help them to make informed decisions rather than reinventing the wheel. Much of the AD research conducted to date describes the already existing professional practices, especially when it comes to what is being described and how (e.g., Chmiel \& Mazur, 2014; Igareda, 2011; Maszerowska, Matamala, \& Orero, 2014; Matamala \& Rami, 2009; Reviers, 2018; Salway, 2007; Szarkowska \& Jankowska, 2015a \& 2015b, among many others). Second, theory can enhance critical thinking about current practices and open-mindedness towards non-standard solutions. Much research has been conducted in the avant-garde of market AD practices, for instance, looking into alternative approaches such as the strategy-based approach (Maszerowska et al., 2014; Remael, Reviers, \& Vercauteren, 2015), reflecting film language in AD (Fryer \& Freeman, 2013), auteur and creative descriptions (Szarkowska \& Wasylczyk, 2014; Walczak \& Fryer, 2017), the use of synthetic voices (Fernández-Torné \& Matamala, 2015; Szarkowska, 2011) or interpreted voicing (Jankowska, Kuniecki, Pilarczyk, \& Wołoszyn-Hohol, 2019). Finally, AD theory provides something that professional practice often lacks: an insight into audience reactions, since much of the AD research involves audience reception studies (e.g., Chmiel \& Mazur, 2016; Fryer \& Freeman, 2014; Ramos Caro, 2015; Vilaró \& Orero, 2013; Walczak, 2017).

However, while theory can provide crucial input that allows for the development of the necessary skills and competences, it is impossible to learn to describe only theoretically hands-on experience is a must. It is through practice and searching for real solutions to real problems that future describers learn how to use the tools provided by theory. While this idea of blending theory and practice sounds convincing, there is an important question that needs to be answered: How does one apply it in a teaching context? In my approach, I try to build practical exercises based on input provided by research. I hope to show how it is done by presenting the exercises I developed for use in describer training.

\section{Sample exercises}

Owing to the limited space available for this article, I present below a selection of the exercises that I have been developing and using for training within and outside of academia since 2009. These exercises are usually embedded in a larger, modular, course on film AD (Jankowska, 2017). The course starts with modules presenting an introduction to the general concept of 
Jankowska, A., (2019). Training future describers - a practice report from an audio description classroom. Linguistica Antverpiensia, New Series: Themes in Translation Studies, 18, 197-215.

accessibility, AD history, current legal status and legislation. Then we move to modules that help to develop knowledge of the rules of film $A D$ and practical $A D$ scripting skills. This article presents sample exercises of the practical AD scripting skills. An important part of the entire course, not discussed here, is contact with real-life assignments and $A D$ users through active participation in access service provision during a film festival (Jankowska, 2017; Jankowska, 2018a). The exercises presented below are grouped - based on my course structure - into five modules: (1) First steps in AD; (2) Translating AD; (3) Learning and questioning the guidelines; (4) From rules to strategies and (5) Collaborative AD scripting. All the proposed exercises can be used in different teaching scenarios: face-to-face, on-line and blended learning. They can serve both as in-class activities and as home assignments.

Although my materials were developed prior to the competence model proposed by the ADLAB PRO project, for the sake of clarity I attempt to frame them within the ADLAB PRO structure. The primary purpose of all the exercises presented below overlaps with some of the main competences put forward by the ADLAB PRO framework, that is to say, to develop "skills for the production of an AD-script for different/selected types of $A D^{\prime \prime}$ (Competence 6) and to acquire "skills for assessing/editing $A D^{\prime}$ " (Competence 8) - see Table 1 below for details. However, they also partially overlap with other competences and sub-competences of the ADLAB PRO framework (see Table 2 below). Some issues included in my training seem not to be present in the ADLAB PRO framework. I discuss them in connection with the specific exercises, but I do not dare to call them 'competences'. As already mentioned, I do not wish to put forward a competence model and decide what is and what is not competence. This article is solely an account of my approach to AD training.

Table 1 Competences 6 and 8 of the ADLAB PRO framework in the proposed exercises.

\begin{tabular}{|c|c|c|}
\hline Module & $\begin{array}{l}\text { ADLAB PRO } \\
\text { Main competences }\end{array}$ & $\begin{array}{l}\text { ADLAB PRO } \\
\text { Domain specific sub-competences }\end{array}$ \\
\hline \multirow{5}{*}{$\begin{array}{l}\text { First steps in } A D \\
\text { Translating AD } \\
\text { Learning and } \\
\text { questioning the } \\
\text { guidelines } \\
\text { From rules to strategies }\end{array}$} & $\begin{array}{l}\text { Competence 6: Skills for the production } \\
\text { of an AD-script for different/selected } \\
\text { types of AD. }\end{array}$ & $\begin{array}{l}\text { General content-related knowledge of } \\
\text { basic rules for all the different types of } \\
\text { AD: what, when and how to describe? }\end{array}$ \\
\hline & $\begin{array}{l}\text { Competence 6b: Knowing what } \\
\text { information to select/prioritize and how } \\
\text { to go about this. }\end{array}$ & $\begin{array}{l}\text { Learners know what information to } \\
\text { select/prioritise (for instance, } \\
\text { characters, facial expressions, dress, } \\
\text { setting, spatial-temporal setting, text- } \\
\text { on-screen). }\end{array}$ \\
\hline & $\begin{array}{l}\text { Competence 6c: Knowing how much } \\
\text { information is necessary and/or } \\
\text { desirable. }\end{array}$ & $\begin{array}{l}\text { Learners know how much information is } \\
\text { necessary and/or desirable. }\end{array}$ \\
\hline & $\begin{array}{l}\text { Competence } 6 \mathrm{~d} \text { : Knowing how to } \\
\text { formulate descriptions and choose the } \\
\text { appropriate } \mathrm{AD} \text { strategies to promote } \\
\mathrm{AD} \text { as a narrative, to ensure clarity and } \\
\text { the production of an engaging text } \\
\text { through linguistic and textual choices. }\end{array}$ & $\begin{array}{l}\text { Learners know how to formulate } \\
\text { descriptions and choose the } \\
\text { appropriate AD strategies (linguistic \& } \\
\text { textual skills, which includes filmic } \\
\text { language and how to deal with it, how } \\
\text { to deal with intercultural references, } \\
\text { subjective approaches to AD, etc.). }\end{array}$ \\
\hline & $\begin{array}{l}\text { Competence 8: Knowledge of the } \\
\text { parameters for a high-quality AD end } \\
\text { product and skills for assessing/editing } \\
\text { the AD. }\end{array}$ & \\
\hline
\end{tabular}


Jankowska, A., (2019). Training future describers - a practice report from an audio description classroom. Linguistica Antverpiensia, New Series: Themes in Translation Studies, 18, 197-215.

Table 2 Other competences of the ADLA PRO framework in the proposed exercises

\begin{tabular}{|l|l|l|}
\hline Module & $\begin{array}{l}\text { ADLAB PRO } \\
\text { Main competences }\end{array}$ & $\begin{array}{l}\text { ADLAB PRO } \\
\text { Domain specific sub-competences }\end{array}$ \\
\hline Translating AD & $\begin{array}{l}\text { Competence 2: General knowledge of } \\
\text { the concept of AD. }\end{array}$ & $\begin{array}{l}\text { Specific knowledge of the needs of the } \\
\text { primary audience (VIP) \& secondary } \\
\text { audiences. }\end{array}$ \\
\cline { 2 - 3 } & $\begin{array}{l}\text { Competence 11: Knowledge of new } \\
\text { developments and the } \\
\text { capacity/willingness to stay abreast. }\end{array}$ & $\begin{array}{l}\text { Students know the challenges of } \\
\text { translating AD and they are aware of } \\
\text { how machine translation and text-to- } \\
\text { speech technologies can be integrated } \\
\text { in the AD process. }\end{array}$ \\
\hline \multirow{2}{*}{$\begin{array}{l}\text { Learning and } \\
\text { questioning the } \\
\text { guidelines }\end{array}$} & $\begin{array}{l}\text { Competence 2: General knowledge of } \\
\text { the concept of AD. }\end{array}$ & $\begin{array}{l}\text { General knowledge of the existence of } \\
\text { standards and guidelines. }\end{array}$ \\
\hline From rules to strategies & $\begin{array}{l}\text { Competence 2: General knowledge of } \\
\text { the concept of AD. }\end{array}$ & $\begin{array}{l}\text { Specific knowledge of the needs of the } \\
\text { primary audience (VIP) \& secondary } \\
\text { audiences. }\end{array}$ \\
\hline Collaborative AD \\
scripting & $\begin{array}{l}\text { Competence 5: Knowledge of the } \\
\text { workflow and identification of the } \\
\text { different people involved in the AD } \\
\text { production process for } \\
\text { different/selected types of AD }\end{array}$ & $\begin{array}{l}\text { Learners know the workflow and } \\
\text { identification of the } \\
\text { different people that may be involved in } \\
\text { the production process of screen AD }\end{array}$ \\
\cline { 2 - 3 } & $\begin{array}{l}\text { Competence 11: Knowledge of new } \\
\text { developments and the } \\
\text { capacity/willingness to stay abreast. }\end{array}$ & $\begin{array}{l}\text { Knowledge of new developments and } \\
\text { the capacity/willingness to stay abreast: } \\
\text { the translation of AD's, use of MT, use } \\
\text { of artificial voices. }\end{array}$ \\
\cline { 2 - 3 } & $\begin{array}{l}\text { Competence 12: Knowledge of new } \\
\text { developments in terms of new areas of } \\
\text { applicability and new audiences. }\end{array}$ & $\begin{array}{l}\text { Students know what crowdsourcing is } \\
\text { and how it can be implemented in AD. }\end{array}$ \\
\hline
\end{tabular}

\subsection{First steps in audio description}

The purpose of the exercises presented below is to give trainees first insights into the challenges of AD drafting and assessing/editing (ADLAB PRO Competences 6, 6b, 6c, 6d and 8), with a particular focus on structuring the description, deciding on the level of detail and knowing how much information is necessary. Two other important issues tackled by these exercises are reflection on the describer's invisibility and the ability to accept feedback.

\subsubsection{Exercise 1: Can you draw it?}

This is one of the very first practical exercises I use in my AD classes. I usually propose it when my trainees are still a tabula rasa, that is to say, when they already know that AD exists and are acquainted with its purposes but are not influenced by any particular $A D$ approach. The point of this exercise is to enable trainees to experience AD from the perspective of a user and to use this experience to deduce possible $A D$ drafting solutions. An essential part of this exercise is for trainees to accept feedback and defend their viewpoint - an important skill for any describer.

Trainees are presented with two manipulated descriptions of the same schematic picture (Figure 1) and asked to draw a picture based on these descriptions. First, they listen to Description 1 (Example 1), which is well structured but imprecise. After completing the first drawing, they listen to Description 2 (Example 1), which is chaotic but very detailed. 
Jankowska, A., (2019). Training future describers - a practice report from an audio description classroom. Linguistica Antverpiensia, New Series: Themes in Translation Studies, 18, 197-215.

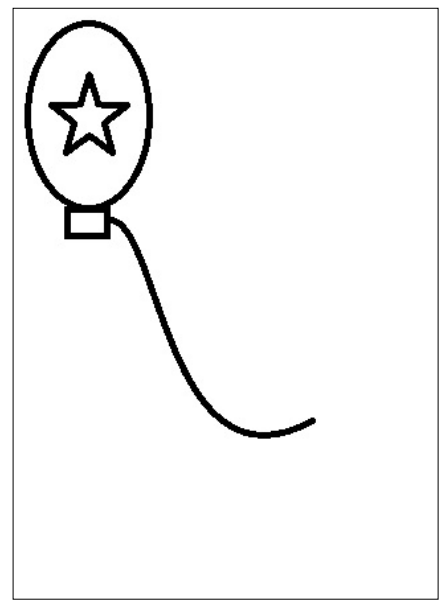

Figure 1: Schematic picture 1 (Sadowska, 2014, p. 134).

Example 1: Sample descriptions of the schematic picture.

\begin{tabular}{|l|l|}
\hline \multicolumn{1}{|c|}{ Description 1 } & \multicolumn{1}{c|}{ Description 2 } \\
\hline $\begin{array}{l}\text { The drawing is on a rectangular piece of paper. In the upper left } \\
\text { corner there is a circle. In the center of the circle there is a five- } \\
\text { pointed star. At the bottom of the circle there is a small } \\
\text { rectangle. A line emerges from it. It gently descends, and then } \\
\text { turns to the right. }\end{array}$ & $\begin{array}{l}\text { The drawing is on a rectangular piece of paper. The paper is } \\
\text { arranged horizontally. In the upper left corner there is an egg- } \\
\text { shaped circle with equal points. It is drawn vertically. The circle is } \\
\text { about two centimeters in height and one centimeter in width. In } \\
\text { the widest and longest points. The top edge of the circle is about } \\
\text { half centimeter away from the top of the image. The left edge of } \\
\text { the circle is about one centimeter away from the left edge of the } \\
\text { drawing. Just below the bottom edge of the circle is a small } \\
\text { rectangle. It is so close to the circle that it seems glued to it. } \\
\text { From the right edge of the rectangle a wave flows. The wave first } \\
\text { gently falls and then more or less in the middle of its length it } \\
\text { gently curves to the right. The wave ends approximately in half } \\
\text { of the length and width of the page. Let's go back to the circle } \\
\text { now. In its center there is a small star. The center of the star is } \\
\text { exactly in the center of the circle. The star has five arms. The first } \\
\text { one is directed vertically upwards. The second and third are } \\
\text { directed straight to the left and straight to the right. Fourth and } \\
\text { fifth are directed diagonally down and to the left and diagonally } \\
\text { down and to the right. }\end{array}$ \\
\hline
\end{tabular}

When the drawings are complete, the trainees present them to their peers and engage in a group discussion to consider which description was easier to follow and why. Ideally, they conclude that descriptions which go from the general to the specific and do not overwhelm with detail are more comfortable to follow.

Drawing from the previous experience, the trainees prepare their descriptions of schematic pictures (Figures 2 and 3 ).

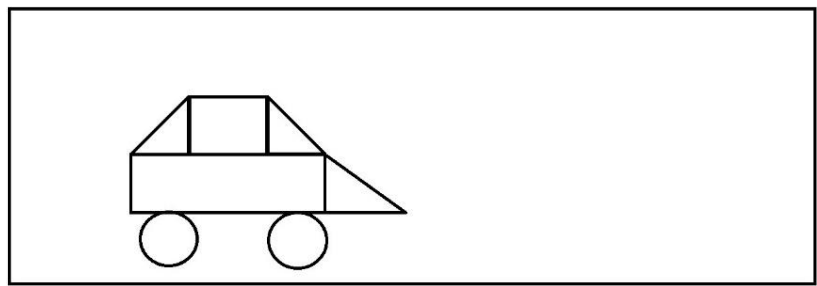

Figure 2: Schematic picture 2 (Sadowska, 2014, p. 134). 
Jankowska, A., (2019). Training future describers - a practice report from an audio description classroom. Linguistica Antverpiensia, New Series: Themes in Translation Studies, 18, 197-215.

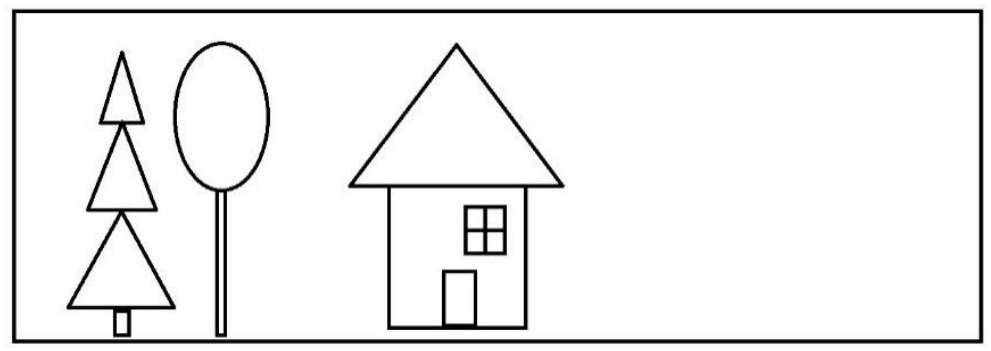

Figure 3: Schematic picture 3 (Sadowska, 2014, p. 134).

They work as partners in pairs. Each trainee in the pair receives a different picture, which they do not show to their partner. Then they take turns and read the descriptions to their partners, who draw. When both drawings are completed, the trainees compare them with the original picture, giving each other feedback on what was challenging to follow and why. Finally, they prepare final versions of the descriptions. For the concluding group discussion, the trainees comment on the changes they introduced to their descriptions and try to justify them. The trainer acts as a moderator and, depending on the students, can adopt various approaches to stimulate the discussion.

\subsubsection{Exercise 2: Can you see what I am seeing?}

This exercise sets out to give the trainees some food for thought about their position as describers and their (in)visibility. The exercise draws from the basic concept of cognitive linguistics - the construal, which refers to the basic human ability to portray the same content in various ways (Langacker, 2008; Taylor, 2002). The way we depict something depends on the distance from which we examine the scene, what we look at in particular, which objects we pay most attention to, where we view the scene from, and on our previous experience or knowledge (Langacker, 2008).

To start the exercise, the trainer places several objects on a table in the middle of the room for example, a small cosmetic purse and its contents. It is important to lay them out in such a way that the trainees, depending on where they sit, see different details. For example, some trainees might see a logo imprinted on the back of a cosmetic case, whereas others will see that the case contains blusher. The trainees are asked to describe what they see in as much detail as possible, but they are not allowed to move from their places.

In the next step, the trainees read the descriptions to their colleagues and engage in a group discussion to discover the factors that influenced their descriptions, that is, where they were looking from (e.g., seeing either a "cosmetic case" or a "rose powder blusher case") and also their general knowledge (e.g., being able to identify the logo and attribute it to a concrete brand). This is followed by a reflection on the describer's role, that is, should they know more than their target audience, should they prepare for their work by familiarizing themselves with documentation and terminology or should they rely exclusively on what they see?

\subsubsection{Exercise 3: Cut it in half and then in half again!}

This exercise explores the issues of time constraints and level of detail. The trainees receive pictures of a famous actor and are asked to prepare a detailed description (approx. 80 words). 
Jankowska, A., (2019). Training future describers - a practice report from an audio description classroom. Linguistica Antverpiensia, New Series: Themes in Translation Studies, 18, 197-215.

When they have finished, the trainees are asked to shorten the description by half and then by half again.

\subsubsection{Exercise 4: Now, you see him?}

This exercise can be used as a starting point for a discussion about what should be prioritized in description and how much the describer should reveal. The trainees receive three different pictures of the same actor (Figure 4) and are asked to describe them - each trainee describes just one picture and is asked not to reveal it to their peers. ${ }^{7}$
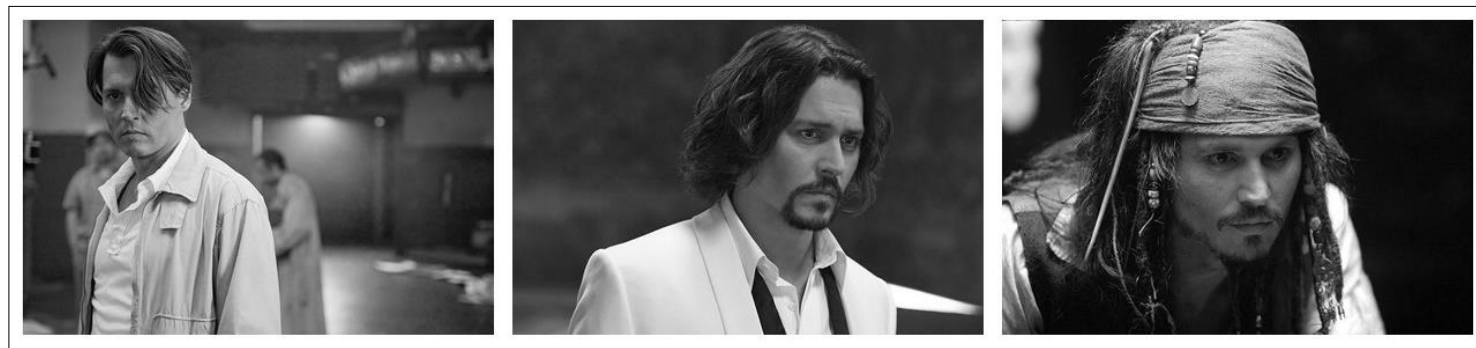

Figure 4: Sample pictures of the same actor (https://www.imdb.com/name/nm0000136/).

Then they read their descriptions out loud. Finally, the pictures are shown to the group and a discussion about what is important in the description follows. Some things that should be considered here are: (1) Should descriptions name the actor on the pictures, make direct reference to the character he represents or describe the characteristic features of the actor and/or character? (2) What if the describer does not know the actor and/or the character he or she impersonates? As in translation, there are no correct answers and, ideally, the trainees conclude that the approach taken might rely mostly on the context, but the approach should be a conscious decision of describers who do not rely solely on what they (think) they see.

\subsection{Translating audio description 8}

Descriptions can be scripted according to three different workflows: by an individual describer, by a team of describers or by an interlingual translation of scripts (Jankowska, 2015). This last workflow, although to date least popular in professional practice, is introduced in training for several reasons. First, it is used as an introduction to AD scripting. On the one hand, it allows trainees to familiarize themselves with descriptions: with style, structure, strategies, choices, etc. On the other hand, the exercises presented below are linked to research results. In this way, they try to raise trainees' awareness of the needs of audiences with vision loss and show them that they might be different from the needs of sighted viewers. The exercises discussed below overlap with Competences 2, 6, 6b, 6c, 6d, 8 and 11 of the ADLAB PRO framework.

\subsubsection{Exercise 1: Who wrote it?}

In this exercise, the trainees familiarize themselves with different styles, structures and strategies of $A D$ by comparing Polish and British AD scripts. The trainees watch six short clips from Harry Potter and the Sorcerer's Stone (Heyman \& Columbus, 2001) and read two different descriptions of each scene: one description is a Polish translation of the English script 
Jankowska, A., (2019). Training future describers - a practice report from an audio description classroom. Linguistica Antverpiensia, New Series: Themes in Translation Studies, 18, 197-215.

written by Diane Langfold and Joan Greening ("Translated script" in Example 2 below, for this article, is presented in the original English version) and the other one is a description drafted originally in Polish ("Written script" in Example 2 below, for this article, is presented in English translation). The trainees receive a handout in which the order of the descriptions in each scene is randomized. At this stage, the trainees do not know which description is translated and which is originally drafted in Polish.

Example 2: Sample of written and translated AD scripts.

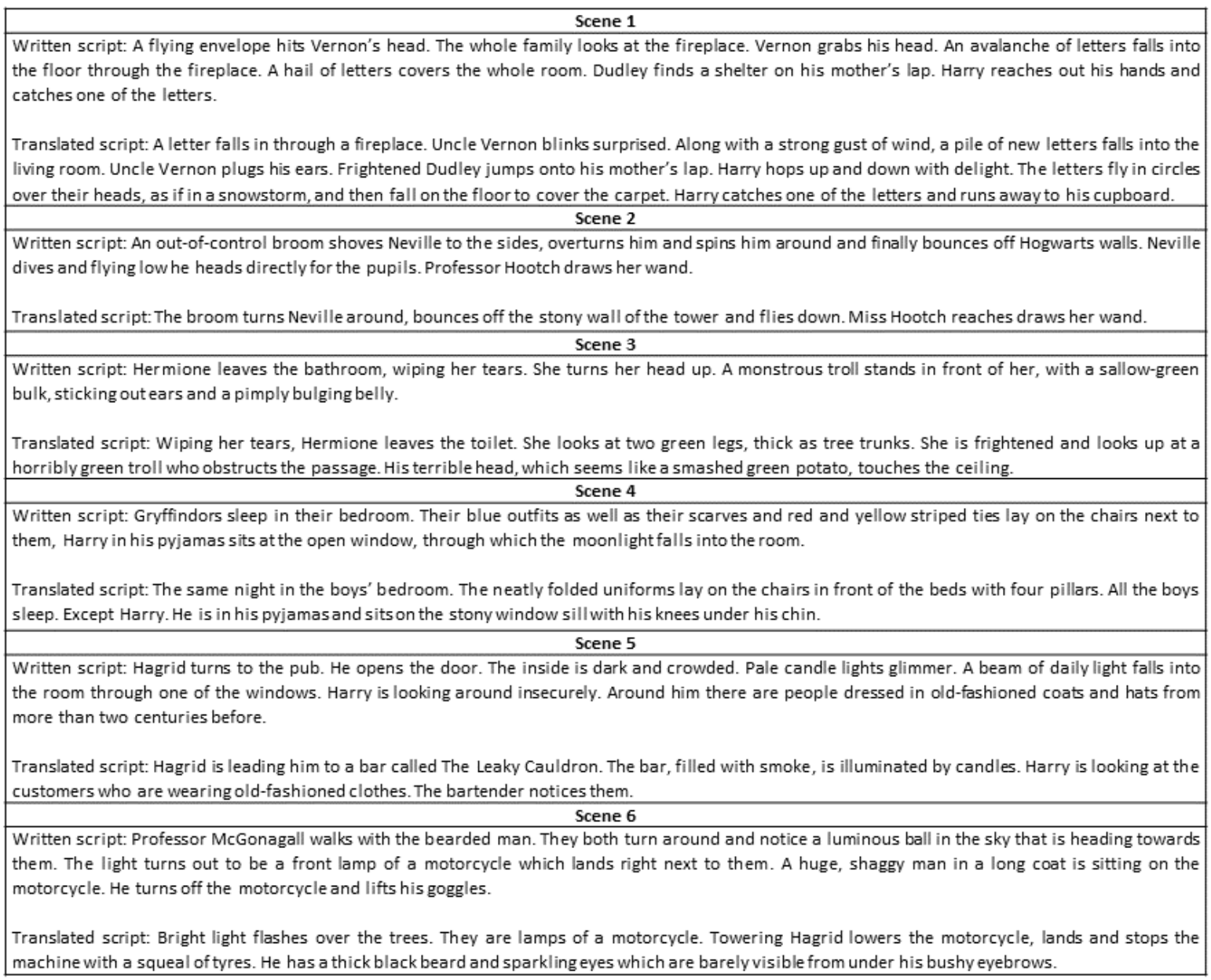

The trainees vote individually to choose their preferred description for each of the scenes and decide which description was written in Polish and which was translated from English. This is followed by a group discussion during which the trainees justify their choices. After that, the results of the survey are presented - preferences and guesses are revealed. The trainees then also learn which descriptions were originally scripted in Polish and which were translated from English. This is followed by a pair or group discussion in which the trainees analyse the descriptions in terms of style, structure and strategies used. Later they try to establish common features of the AD scripted in Polish and that translated from English. 
Jankowska, A., (2019). Training future describers - a practice report from an audio description classroom. Linguistica Antverpiensia, New Series: Themes in Translation Studies, 18, 197-215.

\subsubsection{Exercise 2: What did the audience think? ${ }^{9}$}

The purpose of this exercise is to sensitize the trainees to the needs of the target users and to show them that their needs might differ from those of sighted viewers. They also become familiar with different $A D$ scripting styles. The trainees are presented with the results of a reception study carried out among audiences with and without vision loss. The participants were presented with two descriptions of the same scene and were asked to choose the one they preferred (Jankowska, 2015). The results show that while participants with vision loss preferred translated descriptions, sighted participants opted for those descriptions that were originally drafted in Polish (see Figure 5).

\begin{tabular}{|c|c|c|c|c|c|}
\hline \multicolumn{3}{|c|}{ Experimental group } & \multicolumn{3}{c|}{ Control group } \\
\hline Scene & Written script & Translated script & Scene & Written script & $\begin{array}{c}\text { Translated } \\
\text { script }\end{array}$ \\
\hline $\mathbf{5}$ & $8 \%$ & $92 \%$ & $\mathbf{3}$ & $25 \%$ & $75 \%$ \\
\hline $\mathbf{6}$ & $23 \%$ & $77 \%$ & $\mathbf{1}$ & $50 \%$ & $50 \%$ \\
\hline $\mathbf{1}$ & $25 \%$ & $75 \%$ & $\mathbf{5}$ & $50 \%$ & $50 \%$ \\
\hline $\mathbf{4}$ & $30 \%$ & $70 \%$ & $\mathbf{6}$ & $56 \%$ & $44 \%$ \\
\hline $\mathbf{3}$ & $32 \%$ & $68 \%$ & $\mathbf{4}$ & $62,5 \%$ & $37,5 \%$ \\
\hline $\mathbf{2}$ & $44 \%$ & $56 \%$ & $\mathbf{2}$ & $81 \%$ & $19 \%$ \\
\hline
\end{tabular}

Figure 5: Comparison of preferences of audiences with (experimental group) and without vision loss (control group) (Jankowska, 2015, p. 92).

The trainees analyse the scripts and try to find features that, in their opinion, could justify the preferences. Finally, the trainer presents research results which explain the preferences of both groups: for example, participants with vision loss preferred descriptions that followed a logical chronology rather than camera movements, covered a broader scope of events but in lesser detail, etc. (Jankowska, 2015).

\subsubsection{Exercise 3: To write or to translate?}

In this exercise, the trainees experiment with $A D$ translation to compare it against the more traditional workflow of individual scripting. At the same time, through translation, they familiarize themselves with the different structure, style and strategies of AD. The trainees prepare $A D$ scripts following two workflow types: individual scripting and individual translating. They work in two groups: those in Group A write $A D$ to Clip 1 and then translate $A D$ for Clip 2. Those in Group B first translate AD to Clip 2 and then write AD to Clip 1. While performing both tasks, they are asked to keep track of the time spent on each clip (e.g., through Clocify).

A group discussion follows in which the trainees compare the scripts and the time spent on preparing them. They try to decide whether and how translation helped them in AD writing, whether translation is a valid AD drafting workflow and what its advantages and disadvantages are. 
Jankowska, A., (2019). Training future describers - a practice report from an audio description classroom. Linguistica Antverpiensia, New Series: Themes in Translation Studies, 18, 197-215.

\subsection{Learning and questioning the guidelines}

During the early years of AD development, guidelines were a prominent topic both in research and in practice. To provide quality AD, efforts were made to create both universal (Mazur \& Chmiel, 2012b; Vercauteren, 2007) and national guidelines (Bittner, 2010).

The main aim of the exercises presented below is twofold: on the one hand, they aim at familiarizing trainees with the two sets of Polish AD guidelines (ADLAB PRO Competence 2) and, on the other, they aim to develop a critical approach towards them. The latter is crucial for two interconnected reasons: the status of $A D$ guidelines in Poland and the coexistence of what is sometimes called two AD schools (Jankowska, 2018b). Currently there are two documents: "Standardy tworzenia audiodeskrypcji do produkcji audiowizualnych" [Standards for creating audio description to audiovisual productions] (Szymańska \& Strzymiński, 2010), created by the Fundacja Audiodeskrypcja [Audio Description Foundation] based in Białystok, and "Audiodeskrypcja - zasady tworzenia" [Audio description - rules for creation] (Żórawska, Więckowski, Künstler, \& Butkowska, 2011), created by the Fundacja Kultury Bez Barier [Foundation for Culture Without Barriers] based in Warsaw. The approaches to AD they present, especially when it comes to the issue of objectivity-subjectivity, are so discrepant that some even propose to distinguish between "the Warsaw school of $A D$ " and "the Białystok school of AD" (Jankowska, 2018b, p. 153). However, they do have something in common. Both documents were created based on other guidelines and the personal experience of their authors, although their titles suggest that rather than with "guidelines" we are dealing with "standards". This - as I observed - is very confusing for novice describers, who tend to see these documents as commandments that are not to be questioned.

The exercises presented below are the third version of an exercise that initially consisted of preparing a multimedia presentation on selected guidelines - each group received one document. When I realized that the trainees present the guidelines as if they were laws and regulations that must be followed, the exercise was modified. In a second attempt, the trainees were asked to prepare multimedia presentations comparing selected aspects of both guidelines (e.g., use of metaphors, character naming, description of gestures, emotions, etc.). The intention was for them to contrast the diverging approaches and reflect upon them. However, again, the trainees presented a compilation of "commandments" to be followed. Even if the rules were contradictory, they did not feel that they should be disputed or challenged.

In a third attempt, I tried to take this issue into account, and the exercise was modified yet again. An additional exercise was added before the trainees were asked to prepare the presentation - the students were asked to watch and discuss films with AD prepared following the opposing guidelines. There are two reasons for this. First, additional activities aim to provide trainees with an opportunity to reflect upon the guidelines by contrasting them with real-life descriptions. Secondly, placing the additional exercises before the guidelines are analysed helps to shift the learning process from deductive to inductive. This seems especially important when dealing with guidelines as, I hope, it allows learners to look at them with a critical eye rather than merely accepting them as revealed truth. This is because, while these documents most certainly provided very necessary guidance on how to draft $A D$, they are now perceived as anecdotal and non-research based (Fryer, 2010; Jankowska, 2015; Udo \& Fels, 
Jankowska, A., (2019). Training future describers - a practice report from an audio description classroom. Linguistica Antverpiensia, New Series: Themes in Translation Studies, 18, 197-215.

2011), and research results point to a strategy-based approach in AD (Remael, Reviers, \& Vercauteren, 2015).

\subsubsection{Exercise 1: Which one do you prefer?}

As already explained, this exercise sets out to help trainees discover on their own different AD strategies, especially when it comes to objectivity and subjectivity. The trainees watch two feature films: Krótki Film o Miłości [A Short Film about Love] (Kieślowski, 1978) with AD prepared following the subjective approach and Urodziny [Birthday] (Sobieszczański, 2011) prepared following the objective approach. Both films are freely and legally available on-line. While watching, the trainees are asked to pay special attention to the description of gestures, emotions, characters, sounds and colours as well as the use of metaphors, language and syntax. The viewing is followed by a discussion in which the trainees compare the ADs and express and justify their preferences.

\subsubsection{Exercise 2: What's in the guidelines?}

In this exercise, the trainees learn not only that guidelines exist, but by comparing them, hopefully, they realize that alternative approaches exist in AD. Working in groups, the trainees prepare a 15-minute multimedia presentation on Polish $A D$ guidelines, which is then presented during the course. Both groups analyse both documents - Group A focuses on, for example, metaphors, colours, emotions and Group B on, for instance, characters, gestures, clothes. This allows the trainees to compare the approaches rather than present them as rules.

\subsection{From rules to strategies}

In recent years we have witnessed a significant change regarding the approach towards $A D$ guidelines, one that can be described as a shift from a rule-based approach to a strategy-based approach (Maszerowska et al., 2014; Mazur, 2014; Remael et al., 2015; Szarkowska \& Jankowska, 2015b). The point of the activities presented below is not to question the guidelines, and even less the need for objective descriptions. On the contrary, the activities aim to show the trainees that they can "work with a scale with subjective and objective at the two extremes and varying degrees of objectivity and subjectivity in between rather than with a binary opposition of objective versus subjective" (Mazur \& Chmiel, 2012a, p. 186).

The exercises presented below overlap with ADLAB PRO Competences $2,6,6 b, 6 c$ and $6 d$.

\subsubsection{Exercise 1: Three times lucky}

The purpose of this exercise is to show the trainees that different strategies in AD scriptng are possible and that the choice of a given local strategy depends not only on the general approach but on the context of the described scene. In this exercise, the trainees compare three different descriptions (Example 3) of the same scene from a Polish comedy Seksmisja [Sexmission] (Sołtysik \& Machulski, 1983). Seksmisja is a Polish cult comedy which tells a story of two men who agree to be hibernated in 1991 as part of a scientific experiment. Instead of being woken up in three years - as originally planned - they wake up in 2044 in a post-nuclear world where they are the only two males in a society composed exclusively of women, hostile towards men. In the finale, the two men, disguised as laboratory workers, enter the in-vitro 
Jankowska, A., (2019). Training future describers - a practice report from an audio description classroom. Linguistica Antverpiensia, New Series: Themes in Translation Studies, 18, 197-215.

lab and inject sperm into the incubation machinery. Flashing forward to several months later, a first boy is born.

All the descriptions were taken from existing ADs. Description 1 comes from one of the first ADs ever written in Poland in the 1990s. ${ }^{10}$ Description 2 was written by the Katarynka Foundation and Description 3 by the Audiodeskrypcja Foundation. Each script presents a different approach to the subjectivity/objectivity issue. Trainees are asked to compare the three descriptions, discuss their pros and cons, and choose the one that, in their opinion, suits the context the best or to propose an alternative version. What is vital in this exercise is the fact that, given the context of the film's finale, the most objective Description 3 might be the best fit.

Example 3: Sample of three different descriptions of the same scene.

\begin{tabular}{|l|l|}
\hline Description 1 & $\begin{array}{l}\text { Gentrix Lab. Maks and Albert, wearing white uniforms, enter. Using special } \\
\text { syringes, they inject sperm into test-tubes. }\end{array}$ \\
\hline Description 2 & $\begin{array}{l}\text { Maks and Albert in the lab. It's night-time, so the women are not in the lab. } \\
\text { They perform an in-vitro procedure. }\end{array}$ \\
\hline Description 3 & $\begin{array}{l}\text { The hatchery. Men in white uniforms [...] They approach the incubators with } \\
\text { pipettes full of a white suspension. White suspension mixes with a } \\
\text { transparent liquid. }\end{array}$ \\
\hline
\end{tabular}

\subsubsection{Exercise 2: Let's do it differently!}

This exercise evolves around an alternative/subjective approach to AD scripting and, once again, aims at showing the trainees that different approaches to $A D$ are possible. The trainees work with a trailer for the Rio Paralympics - Audio Described: We're The Superhumans (Channel 4, 2016). The trailer, available online, has a very particular description in which both the text and the vocal delivery are very lively. The trainees are asked first to listen to the trailer's audio and then to see the clip. After that they are encouraged to engage in a discussion about this non-standard approach, to comment on how it is different from the standard ADs, to discuss its possible pros and cons and to consider whether they like it and whether the audiences with vision loss would enjoy it.

\subsubsection{Exercise 3: Have you ever seen a robin?}

The purpose of this exercise is to show to the trainees that different approaches can be used when scripting AD. They are also encouraged to compare them, discuss their pros and cons and reflect on how the context of the scene and the film influences the choice of approach. In this exercise, the trainees compare two different descriptions of the opening scene of the blockbuster movie Gladiator (Scott, 2000). Both descriptions are based on real descriptions that were prepared for the Krakow Film Music Festival in 2014. However, both descriptions were manipulated so that they are more extreme in terms of subjectivity/objectivity and scope and level of detail. Version B is a first draft prepared by a volunteer and Version A is based on the final version, proofread by an experienced describer. 
Jankowska, A., (2019). Training future describers - a practice report from an audio description classroom. Linguistica Antverpiensia, New Series: Themes in Translation Studies, 18, 197-215.

Example 4: Two different descriptions of Gladiator opening scene.

\begin{tabular}{|l|l|}
\hline VERSION A & VERSION B \\
\hline $\begin{array}{l}\text { A close-up. A male hand strokes golden ears } \\
\text { of rye. A silver signer on his ring finger. }\end{array}$ & $\begin{array}{l}\text { Sunny, summer afternoon. A man walks } \\
\text { peacefully through a field of grains. } \\
\text { The man is wearing leather armour. } \\
\text { He walks peacefully among the fields } \\
\text { stretching to the horizon. }\end{array}$ \\
$\begin{array}{l}\text { A silver signet shines on the ring finger of } \\
\text { his left hand. He gently strokes the golden } \\
\text { ears of grains. }\end{array}$ \\
$\begin{array}{l}\text { old brunet with a slight beard lifts his head. } \\
\text { he looks away. A wolf skin draped around } \\
\text { robin sitting on a bare branch. The winter } \\
\text { wind brings smoke. The bird flies away, the } \\
\text { man looks after him and smiles. Suddenly } \\
\text { he becomes serious and leaves. }\end{array}$ & $\begin{array}{l}\text { A gloomy day. General Maximus, a 30-year- } \\
\text { old brunet with a slight beard stands against } \\
\text { the background of leafless bushes. He is } \\
\text { dressed in the legionnaire's armour. Wolf's } \\
\text { skin draped around his shoulders. He raises } \\
\text { his head. He looks ahead, absentminded } \\
\text { Suddenly, he comes back to reality. } \\
\text { He glances around, frowning and walks } \\
\text { away. Around him a muddy battlefield, } \\
\text { broken, burning threes and a forest in the } \\
\text { distance. }\end{array}$ \\
\hline STUDENT'S VERSION
\end{tabular}

After seeing the scene and reading the descriptions, the trainees compare both versions and engage in a discussion about the choices of the describers - in terms of both what has been described and how it has been described. The level of detail and objectivity are under the spotlight during this discussion. Finally, the trainees - working in groups, pairs or individually - are asked to produce their own descriptions of the two scenes.

\subsubsection{Exercise 4: Relativity of time!}

This exercise, again, exploits the issue of choosing the appropriate AD strategies. The focus is the artistic vision of the described film but also the available time, which requires compromise. The exercise develops around a very peculiar video that is freely available online: Epic Tea Time with Alan Rickman (Michalek, 2012). The original video is about 7 minutes long. It presents - in extreme slow motion - a scene in which Alan Rickman is seated behind a desk in a dark room. Rickman's actions are at first "limited" to dropping a tea bag and a lemon slice into a mug of water and stirring the contents. In an emotional finale, Rickman throws the mug and overturns the desk. The slow-motion filming evokes the power of emotion and dramatic ability. It also allows the viewer to see all that usually goes unnoticed - for example, melodramatic spills of water, intense swirls of the tea bag string, the actor's striking mimicking that reveal the movement of every single facial muscle.

For the activity itself, two edited versions of the film are used: the official film (Michalek, 2012) in dramatic time (approx. 7 minutes) and an unofficial re-edit (Monteith, 2012) in real-time (approx. 11 seconds). The trainees are asked to draft the AD script twice. First, they draft AD to the long clip and only after it is completed are they asked to see the short clip and rewrite their script so that it fits into the time available.

Afterwards, they engage in a discussion on adapting the description to time restrictions, the video's style, and the artistic vision. 
Jankowska, A., (2019). Training future describers - a practice report from an audio description classroom. Linguistica Antverpiensia, New Series: Themes in Translation Studies, 18, 197-215.

\subsection{Collaborative AD scripting}

Although collaborative AD scripting is a workflow overlooked by research, it is used in professional practice to speed up the work on AD scripting when time is short (Jankowska, 2018a). To give some examples: it is a common practice to assign more than one describer to a series season or even to a film (e.g., one describer writes $A D$ for the first half of the series or film and the other the second half) (A. Psiuk, personal communication, 20 November 2018; S. Yousaf, personal communication, 22 November 2018).

Collaborative $A D$ scripting requires proper planning and an ability to adjust one's personal scripting style so that the final script is homogenous. The exercises presented below overlap with ADLAB PRO Competences 5, 6, 6b, 6c, 6d, 11 and 12.

\subsubsection{Exercise 1: Trading places}

The purpose of this exercise is to introduce the trainees to the new AD workflow collaborative scripting - and through a first-hand experience encourage them to reflect on its pros and cons. In this exercise, the trainees are asked to prepare AD to a clip from a series or a film (approx. 5 minutes) in a restricted time of 30 minutes. After 15 minutes - without warning - the trainees are asked to change places, for example, to move one computer to the right and continue scripting from whichever place their colleague finished at. They are not given any extra time, so they have to adapt to what has already been written rather than correct it. Once finished, the students engage in a group discussion, during which they reflect on the pros, cons and challenges of collaborative AD scripting.

\subsubsection{Exercise 2: Let's work together}

In this exercise, the trainees learn about the workflow in collaborative $A D$ scripting and identify the people, processes and tools involved in it. The trainees work together in a team of 3-5. They are asked to produce an AD script to a film clip, assuming the roles of a project manager, describers and proofreaders. They work in a cloud environment using tools such as Dropbox/Google drive for AD scripting and ASANA for project management. They work remotely and contact the trainer through email as if the trainer were their client. After completing the task, in a class discussion, the trainees reflect upon the pros and cons of collaborative scriptng and propose improvements to the process.

\section{Conclusions}

In this article, I have presented some of the exercises I have been developing and testing, using the old-fashioned method of trial and error, since 2009. I also tried to frame them within the ADLAB PRO framework of competences of professional audio describer - and I am happy to say that they seem to fit.

The exercises presented are by no means a complete or systematic teaching curriculum, but I sincerely hope that they do help to train successful describers who can provide a quality service. 
Jankowska, A., (2019). Training future describers - a practice report from an audio description classroom. Linguistica Antverpiensia, New Series: Themes in Translation Studies, 18, 197-215.

Do they work? Currently, three of my now ex-trainees are involved in the everyday work of the NGO we established in 2011 with yet another former student. Six more collaborate with us on a less regular basis, one is pursuing her PhD in media accessibility, and five more have just finished their summer internship with us and are staying on. I think it is safe to say "yes, they did". This is merely a personal opinion, however. I strongly believe that formal tests of the approach and exercises discussed in this article are needed. And so is a comprehensive framework for describers' training and structured training materials - ADLAB PRO is an important step in this direction.

\section{Acknowledgements}

This work has been supported by the research grant "ECR transfer in audio description" no. 1311/MOB/IV/2015/0 of the Polish Ministry of Science and Higher Education for the years 2016-2019.

\section{References}

Access2Arts. (n.d.). Thinking about becoming an audio describer? Retrieved from https://access2 arts.org.au/wp-content/uploads/2016/10/AD_FAQs_Describers.pdf

ADLAB PRO. (2018). Simplified course structure. Retrieved from https://www.adlabpro.eu/wp-content /uploads/2018/11/Simplified-course-structure-I03-1.pdf

Audio Description Association. (n.d.). ADA training - screen. Retrieved from http://audiodescription. co.uk/training/accredited-training-screen/

Biel, Ł. (2013). Integracyjne podejście funkcjonalne w dydaktyce przekładu prawniczego. Między Oryginałem a Przekładem, 19(21), 11-27. doi:10.12797/moap.19.2013.21.02

Bittner, H. (2010). Audio description guidelines:A comparison. Retrieved from https://www.unihildes heim.de/media/_migrated/content_uploads/AD_Guidelines_Comparison_-_Read.pdf

Bonwell, C., \& Eison, J. (1991). Active learning: Creating excitement in the classroom. Retrieved from https://files.eric.ed.gov/fulltext/ED336049.pdf

Channel 4 (Producer). (2016, July, 14). Audio described: We're the superhumans [Video file]. Retrieved from https://www.youtube.com/watch?v=EKGOWavFvHc

Chmiel, A., \& Mazur, I. (2014). Audiodeskrypcja. Retrieved from https://repozytorium.amu.edu.pl/bit stream/10593/12861/1/Audiodeskrypcja_Chmiel_Mazur_2014.pdf

Chmiel, A., \& Mazur, I. (2016). Researching preferences of audio description users: Limitations and solutions. Across Languages and Cultures, 17(2), 271-288. doi:10.1556/084.2016.17.2.7

Heyman, D. (Producer), \& Columbus, C. (Director). (2001). Harry Potter and the philosopher's stone [Motion picture]. United Kingdom: Warner Bros. Pictures.

Díaz-Cintas, J. (2007). Por una preparación de calidad en accesibilidad audiovisual. TRANS: Revista de Traductología, 11, 45-60. doi:10.24310/TRANS.2007.v0i11.3097

European Commission. (2017). European master's in translation: Competence framework. Retrieved from http://relaunch.ecompetences.eu/wp-content/uploads/2013/11/EQF_broch_2008_en.pdf

Evangelina, K., Peralta, B., Guajardo, A. G., Sotomayor, M., \& Lemus, M. Á. (n.d.). Developing audio description competencies as part of a translation education program. Retrieved from http:// idiomas.ens.uabc.mx/plurilinkgua/docs/v5/1/developing.pdf

Felder, R. M., Celanese, H., \& Brent, R. (2009). Active learning: An introduction*. ASQ Higher Education Brief, 2(4), 1-5. Retrieved from https://www.engr.ncsu.edu/stem-resources/legacy-site/educa tion-related-papers/active-learning-introduction/

Fernández-Torné, A., \& Matamala, A. (2015). Text-to-speech vs. human voiced audio descriptions: A reception study in films dubbed into Catalan. JoSTrans: The Journal of Specialized Translation, 24, 
Jankowska, A., (2019). Training future describers - a practice report from an audio description classroom. Linguistica Antverpiensia, New Series: Themes in Translation Studies, 18, 197-215.

61-88.

Fryer, L. (2010). Directing in reverse. In I. Kemble (Ed.), The changing face of translation, proceedings of the 9th Annual Portsmuth Translation Conference (pp. 63-72). Retrieved from http://www. port.ac.uk/media/contacts-and-departments/slas/events/tr09-fryer.pdf

Fryer, L. (2016). An introduction to audio description: A practical guide. London: Routledge. doi:10. $4324 / 9781315707228$

Fryer, L., \& Freeman, J. (2013). Cinematic language and the description of film: Keeping AD users in the frame. Perspectives: Studies in Translatology, 21(3), 412-426. doi:10.1080/0907676X.2012.6931 08

Fryer, L., \& Freeman, J. (2014). Can you feel what I'm saying?: The impact of verbal information on emotion elicitation and presence in people with a visual impairment. In A. Felnhofer \& O. D. Kothgassner (Eds.), Proceedings of the international society for presence research 2014 (pp. 99107). Wien: Facultas.

Hurtado Albir, A. (Ed.). (2017). Researching translation competence by PACTE group. Amsterdam: John Benjamins. doi:10.1075/btl.127

Hyks, V. (2005). Audio description and translation: Two related but different skills. Translating Today, $4,6-8$.

Igareda, P. (2011). The audio description of emotions and gestures in Spanish-spoken films. In A. Şerban, A. Matamala, \& J.-M. Lavaur (Eds.), Audiovisual translation in close-up (pp. 223-238). Bern: Peter Lang.

Jankowska, A. (2015). Translating audio description scripts: Translation as a new strategy of creating audio description. Frankfurt am Main: Peter Lang. doi:10.3726/978-3-653-04534-5

Jankowska, A. (2017). Blended learning in audio description training. Między Oryginałem a Przekładem, 38(4), 101-124. doi:10.12797/MOaP.23.2017.38.05

Jankowska, A. (2018a, June). How AD translation can lead us to quality: Translation, crowdsourcing, collaboration and quality in audio description. Paper presented at UMAQ Conference, Barcelona. Retrieved from https://www.academia.edu/38045979/TRANSLATION_CROWDSOURCING_COL LABORATION_AND_QUALITY_IN_AUDIO_DESCRIPTION

Jankowska, A. (2018b). Patrząc w przeszłość, patrząc w przyszłość: 10 lat audiodeskrypcji filmowej w Polsce. Między Oryginałem a Przekładem, 39, 139-158. doi:10.12797/MOaP.24.2018.40.08

Jankowska, A., Kuniecki, M., Pilarczyk, J., \& Wołoszyn-Hohol, K. (2019). Interpreted vs. non-interpreted voicing in audio description. Manuscript submitted for publication.

Kieślowski, K. (Director). (1978). Krótki film o miłości [A short film about love] [Motion picture]. Poland: Studio Filmowe TOR. Retrieved from http://adapter.pl/?movie=krotki-film-o-milosci

Langacker, R. W. (2008). Cognitive grammar: A basic introduction. Oxford: Oxford University Press. doi: 10.1093/acprof:oso/9780195331967.001.0001

Maszerowska, A., Matamala, A., \& Orero, P. (Eds.). (2014). Audio Description: New perspectives illustrated. Amsterdam: John Benjamins. doi:10.1075/btl.112

Matamala, A. (2006). La accesibilidad en los medios: aspectos lingüísticos y retos de formación. In R. Amat \& Á. Pérez-Ugena (Eds.), Sociedad, integración y televisión en España (pp. 293-306). Madrid: Laberinto.

Matamala, A., \& Orero, P. (2007). Designing a course on audio description and defining the main competences of the future professional. Linguistica Antverpiensia, New Series - Themes in Translation Studies, 6, 329-344.

Matamala, A., \& Rami, N. (2009). Análisis comparativo de la audiodescripción española y alemana de "Goodbye, Lenin". Hermeneus. Revista de Traducción e Interpretación, 11, 249-266.

Mazur, I. (2014). Projekt ADLAB i funkcjonalizm w przekładzie - w stronę strategii audiodeskrypcyjnych. Przekładaniec, 28, 11-22. doi:10.4467/16891864PC.14.001.1708

Mazur, I., \& Chmiel, A. (2012a). Audio description made to measure: Reflections on interpretation in $A D$ based on the pear tree project data. In Audiovisual translation and media accessibility at the 
Jankowska, A., (2019). Training future describers - a practice report from an audio description classroom. Linguistica Antverpiensia, New Series: Themes in Translation Studies, 18, 197-215.

crossroads. Media for all 3 (pp. 173-188). Retrieved from http://wa.amu.edu.pl/publica tions/node/3400 doi:10.1163/9789401207812_011

Mazur, I., \& Chmiel, A. (2012b). Towards common European audio description guidelines: Results of the pear tree project. Perspectives, 20(1), 5-23. doi:10.1080/0907676X.2011.632687

Michalek, D. (2012, May, 12). Epic tea time with Alan Rickman [Video file]. Retrieved from https:// www.youtube.com/watch?v=eob7V_WtAVg\&t=161s

Monteith, A. (2012, May, 14). Alan Rickman: Portraits in real time [Video file]. Retrieved from https:// www.youtube.com/watch?v=UYgLVHy2wi4

Navarrete Moreno, F. J. (1997). Sistema AUDESC: el arte de hablar en imágenes. Integración, 23, 7082. Retrieved from http://www.once.es/new/servicios-especializados-en-discapacidad-visual/pu blicaciones-sobre-discapacidad-visual/nueva-estructura-revista-integracion/copy_of_numerospublicados/integracion-pdf/Integracion-23.pdf

Orero, P. (2005). Audio description: Professional recognition, practice and standards in Spain. Translation Watch Quarterly , 1, 7-18.

Ramos Caro, M. (2015). The emotional experience of films: Does audio description make a difference? Translator, 21(1), 68-94. doi:10.1080/13556509.2014.994853

Remael, A., Reviers, N., \& Vercauteren, G. (Eds.). (2015). Pictures painted in words: ADLAB audio description guidelines. Trieste: EUT Edizioni Università di Trieste. Retrieved from https://www. openstarts.units.it/handle/10077/11838

Reviers, N. (2018). Studying the language of Dutch audio description. Translation and Translanguaging in Multilingual Contexts, 4(1), 178-202. doi:10.1075/ttmc.00009.rev

Sadowska, A. (2014). Audiodeskrypcja do ilustracji w prasie [Audio description of press illustrations]. Przekładaniec, (28), 124-139. doi:10.4467/16891864PC.14.009.1716

Salway, A. (2007). A corpus-based analysis of audio description. In J. Díaz-Cintas, P. Orero, \& A. Remael (Eds.), Media for all: Subtitling for the Deaf, audio description and sign language (pp. 151-174). Amsterdam: Rodopi. doi:10.1163/9789401209564_012

Scott, R. (Director). (2000). Gladiator. United States: Dreamworks Universal Pictures.

Snyder, J. (2014). The visual made verbal: A comprehensive training manual and guide to the history and applications of audio description. Retrieved from http://www.thevisualmadeverbal.net/ index.php

Sobieszczański, M. (2011). Urodziny [Birthday] [Motion picture]. Poland: Studio Munka, Stowarzyszenie Filmowców Polskich, Telewizja Polska S.A. Retrieved from https://ninateka.pl/ film/urodziny-maciej-sobieszczanski

Sołtysik, A. (Producer), \& Machulski, J. (Director) (1983). Seksmisja [Sexmission] [Motion picture]. Poland: Zespół Filmowy Kadr.

Szarkowska, A. (2008). Przekład audiowizualny w Polsce: Perspektywy i wyzwania [Audiovisual translation in Poland: Perspectives and challenges]. Przekładaniec, 20, 8-25.

Szarkowska, A. (2011). Text-to-speech audio description: Towards wider availability of AD. Jostrans. The Journal of Specialised Translation, 15, 142-162.

Szarkowska, A., \& Jankowska, A. (2015a). Audio describing foreign films. Jostrans. The Journal of Specialised Translation, (23), 243-269.

Szarkowska, A., \& Jankowska, A. (2015b). Audio subtitling multilingual films in Poland: Early developments, current practices and future challenges. In A. Jankowska \& A. Szarkowska (Eds.), New points of view on audiovisual translation and media accessibility (pp. 191-218). Oxford: Peter Lang.

Szarkowska, A., \& Wasylczyk, P. (2014). Audiodeskrypcja autorska [Auteur audio description]. Przekładaniec, 28, 48-62. doi:10.4467/16891864PC.14.004.1711

Szymańska, B., \& Strzymiński, T. (2010). Standardy tworzenia audiodeskrypcji do produkcji audiowizualnych [Standards for creating audio description to audiovisual productions]. Retrieved from http://avt.ils.uw.edu.pl/files/2010/12/AD__standardy_tworzenia.pdf 
Jankowska, A., (2019). Training future describers - a practice report from an audio description classroom. Linguistica Antverpiensia, New Series: Themes in Translation Studies, 18, 197-215.

Taylor, J. R. (2002). Cognitive grammar. Oxford: Oxford University Press.

Udo, J. P., \& Fels, D. I. (2011). From the describer's mouth: Reflections on creating unconventional audio description for live theatre. In A. Şerban, A. Matamala, \& J.-M. Lavaur (Eds.), Audiovisual translation in close-up (pp. 257-278). Bern: Peter Lang.

Vercauteren, G. (2007). Towards a European guideline for dudio Description. In J. Díaz-Cintas, P. Orero, \& A. Remael (Eds.), Media for all: Subtitling for the Deaf, audio description and sign language (pp. 139-150). doi:10.1163/9789401209564_011

Vilaró, A., \& Orero, P. (2013). The audio description of leitmotifs. International Journal of Humanities and Social Science, 3(5), 56-64.

Walczak, A. (2017). Immersion in audio description: The impact of style and vocal delivery on users' experience (Unpublished doctoral dissertation). Universitat Autònoma de Barcelona, Barcelona, Spain.

Walczak, A., \& Fryer, L. (2017). Creative description: The impact of audio description style on presence in visually impaired audiences. British Journal of Visual Impairment, 35(1), 6-17. doi:10.1177/026 4619616661603

Żórawska, A., Więckowski, R., Künstler, I., \& Butkowska, U. (2011). Audiodeskrypcja: Zasady tworzenia [Audio description: Rules for creation]. Retrieved from http://dzieciom.pl/wp-content/uploads/ 2012/09/Audiodeskrypcja-zasady-tworzenia.pdf

1 The UN Convention on the Rights of Persons with Disabilities, https://www.un.org/develop ment/desa/disabilities/convention-on-the-rights-of-persons-with-disabilities.html

2 Audiovisual Media Services Directive, https://eur-lex.europa.eu/legal-content/EN/ALL/?uri=CELE X:32010L0013

3 For more information on legislation organized by countries see https://mapaccess.uab.cat/accesso meter

4 European Accessibility Act, https://eur-lex.europa.eu/legal-content/EN/TXT/?uri=uriserv:OJ.L_. 2019.151.01.0070.01.ENG\&toc=OJ:L:2019:151:TOCEuropean Accessibility Act, https://eur-lex.eu ropa.eu/legal-content/EN/TXT/?uri=uriserv:OJ.L_.2019.151.01.0070.01.ENG\&toc=OJ:L:2019:151: TOC

5 A non-exhaustive list of training courses can be found at https://mapaccess.uab.cat/training https://mapaccess.uab.cat/training

6 ADLABPRO (2016-2019) project financed by the European Union under the Erasmus+ Programme, Key Action 2 - Strategic Partnerships, www.adlabpro.eu.

7 This exercise is inspired by a similar exercise proposed by Matamala and Orero (2007, p. 340).

8 Please note that Exercises 1 and 2 do not require the trainees to have any translation or foreign language skills.

9 This exercise builds upon the previous one; however, it can also be used as a stand-alone exercise. In this case the trainer should also prepare a handout with descriptions of the scenes.

10 In the late 1990s and early 2000s Poland produced 20 of the so-called typhlofilms for audiences with vision loss. They used freeze frame (stopping of the picture and sound) whenever description would not fit between the dialogues. To read more on typhlofilms see Chmiel \& Mazur, 2014; Jankowska, 2015; Szarkowska, 2008. 